PUBLISHER CORRECTION

\title{
Publisher Correction: Application of full-genome analysis to diagnose rare monogenic disorders
}

Joseph T. Shieh (D), Monica Penon-Portmann (D), Karen H. Y. Wong (D), Michal Levy-Sakin, Michelle Verghese (iD, Anne Slavotinek (iD, Renata C. Gallagher (iD, Bryce A. Mendelsohn (D), Jessica Tenney, Daniah Beleford, Hazel Perry, Stephen K. Chow, Andrew G. Sharo (iD, Steven E. Brenner (D), Zhongxia Qi, Jingwei Yu, Ophir D. Klein (D), David Martin, Pui-Yan Kwok (D) and Dario Boffelli

npj Genomic Medicine (2021)6:88; https://doi.org/10.1038/s41525-021-00251-3

Correction to: npj Genomic Medicine https://doi.org/10.1038/s41525021-00241-5, published online 23 September 2021

"The original version of the published Article contained additional text that was inadvertently inserted in the first line of the abstract. The following text was removed from the abstract to improve clarity: 'enhancer and narrows the diagnostic interval'. The HTML and PDF versions of the Article have been corrected."

\begin{abstract}
Open Access This article is licensed under a Creative Commons Attribution 4.0 International License, which permits use, sharing, adaptation, distribution and reproduction in any medium or format, as long as you give appropriate credit to the original author(s) and the source, provide a link to the Creative Commons license, and indicate if changes were made. The images or other third party material in this article are included in the article's Creative Commons license, unless indicated otherwise in a credit line to the material. If material is not included in the article's Creative Commons license and your intended use is not permitted by statutory regulation or exceeds the permitted use, you will need to obtain permission directly from the copyright holder. To view a copy of this license, visit http://creativecommons. org/licenses/by/4.0/.
\end{abstract}

(c) The Author(s) 2021 